\title{
The Effect of Hazelnut Husk Enriched With Organic Fertilizer on Mineral Content of Rocket and Cress
}

\author{
Atnan Ugur \\ Department of Horticulture, Faculty of Agriculture, Ordu University, Ordu, 52200 Turkey \\ Gulnur Karaal Bozkurt \\ Kabaduz District Directorate of Food, Agriculture and Livestock, Ordu, 52020, Turkey
}

\begin{abstract}
The study was carried out in the unheated plastic tunnel greenhouse and using hazelnut husk compost as a growing medium for cress and rocket plants. In the study effect of natural hazelnut husk compost enriched with organic fertilizer at different ratios content of rocket and cress minerals were investigated. Commercial organic fertilizer was added to hazelnut husk compost with nitrogen content of 1, 2, 3 and $4 \%$ of growing medium. Hazelnut husk compost are accepted as control applications. The research was set up in a trial design with 3 repeatable random parcels. Cultivation is made in plastic balcony type pots and every pot is accepted as a recurrence of application. Seed sowing $(2 \mathrm{~g} / \mathrm{m} 2)$ was carried out in two periods, 10 September in autumn and April 28 in spring. The plants were harvested twice in both growing periods. Nitrogen, phosphorus and potassium contents were determined in plant samples after harvesting. In the study, it was seen that the application of organic fertilizers had statistically significant changes in mineral contents of cress and rocket plants. With the addition of organic fertilizers, the content of nitrogen, phosphorus and potassium is increased in rocket and cress. Mineral material content was found to be high in the autumn period and first harvest. The mineral content of the cress was higher than the rocket plants.
\end{abstract}

Keywords: Eruca sativa, Lepidium sativum, hazelnut husk, fertilizer, nitrogen, phophorus, potassium

DOI: $10.7176 / J S T R / 5-7-14$

\section{Organik Gübre ile Zenginleştirilen Fındık Zuruf Kompostu Ortamının Roka ve Terede Mineral Madde İçeriklerine Etkisi}

\begin{abstract}
Özet
Tere ve rokada yetiștirme ortamı olarak findık zuruf kompostunun kullanıldığı çalıșma, ısıtmasız plastik tünel tipi serada yürütülmüştür. Çalışmada farklı oranlarda organik gübre ile zenginleştirilmiş findık zuruf kompostunun roka ve terenin mineral madde içerikleri üzerine etkisi araştırılmıştır. Yetiştirme ortamının azot içeriği \% 1, 2, 3 ve 4 oranında olacak şekilde findık zuruf kompostuna ticari organik gübre ilave edilmiştir. Fındık zurufu kompostu ise kontrol uygulaması olarak kabul edilmiştir. Araştırma 3 tekerrürlü tesadüf parselleri deneme deseninde kurulmuştur. Yetiştiricilik plastik balkon tipi saksılarda yapılmış ve her saksı bir uygulama tekerrürü olarak kabul edilmiştir. Sonbahar döneminde 10 Eylül, ilkbahar döneminde 28 Nisan'da olmak üzere iki dönemde tohum ekimi $(2 \mathrm{~g} / \mathrm{m} 2)$ yapılmıştır. Bitkilerde her iki yetiştirme döneminde de ikişer kez hasat yapılmıştır. Hasat sonrası bitki örneklerinde azot, fosfor ve potasyum içerikleri belirlenmiştir. Çalışmada organik gübre uygulamaları ile roka ve terede mineral madde içerikleri üzerine istatistiksel anlamda değişimlerin olduğu görülmüştür. Organik gübre ilavesi ile roka ve terede azot, fosfor ve potasyum içerikleri artmıştır. Sonbahar dönemi yetiştiricilik ve ilk hasatlarda mineral madde içerikleri yüksek bulunmuştur. Terenin mineral madde içeriğinin rokaya göre daha fazla olduğu görülmüştür.
\end{abstract}

Anahtar sözcükler: Eruca sativa, Lepidium sativum, findık zurufu, gübreleme, azot, fosfor, potasyum 


\section{Giriș}

Son yıllarda besin içerikleri ve özellikle insan sağlı̆̆ına olan olumlu etkileri nedeniyle sebze tüketimi artmıștır (Chang et al. 2013; Khanam et al. 2012). Roka (Eruca sativa) ve tere (Lepidium sativum) Akdeniz diyetinin sebzelerindendir. Her iki sebze ülkemizin de içinde yer aldığı coğrafyada bol miktarlarda üretilmekte ve tüketilmektedir (Demir 2007). Roka ve tere hemen hemen her mevsim üretilmektir, ancak tere üretimi yüksek sıcaklıklar nedeniyle yaz aylarında daha sınırlıdır (Eşiyok 2012). Mutedil iklim koşullarında bu bitkilerin gelişimi çok hızlı olmakta ve 20-30 günde hasada gelmektedirler. Bitki yapraklarının keskin baharatlı-aromalı tatları, iştah açıcı özellikleri, sağlık etkileri ve besleyici değerlerinin yüksek olması ile dikkat çekicidirler (Vural ve ark. 2000; Gutierrez et al. 2016).

Yeşillikler mevsimsel iklim değişimine karşı çok hassas olmaları nedeniyle ilkbahar ve sonbahar aylarında yetiştirildiğinde tüketilen kısım olan yapraklarda kalite sorunları olabilmektedir. Bunların en önemlisi bitkinin generatif büyümeye geçerek çiçek oluşturma davranışı göstermesidir (Eşiyok ve ark. 2006b; Morales and Janick 2002). Bununla birlikte kısa vegetasyonlu yeşilliklerde ilkbahar aylarında görülen düşük ışık yoğunluğu ve süreklilik arz eden yağışlar bitkilerin daha fazla nitrat akümüle etmesine neden olmaktadır (Chang et al. 2013; Colonna et al. 2016). Karadeniz Bölgesi iklim koşullarında benzer durumlara sıklıkla rastlanmaktadır. Son yıllarda aşırı nitrat alınımının insan sağlı̆̆ına zararlı etkilerinin ortaya konması azotlu gübre miktarları ve gübrelerin verilme formunda bazı kısitlamaların ortaya çıkmasına yol açmıştır. Sağlık konusundaki bazı çekinceler nedeniyle azotlu gübre uygulamalarında etkili doz konusunda çalışmalar artmaya başlamıştır (Eşiyok ve ark. 2006b; Nicola et al. 2005; Nicola et al. 2007; Santamaria and Elia 1997; Santamaria et al. 2002). Sebze yetiştiriciliğinde daha az gübre kullanımı hem ekonomik hem de çevresel sürdürülebilirlik açısından olumlu katkılar sunmaktadır. Standart, temiz ve kontrollü bir yeşillik üretimi için topraksız kültür iyi bir seçenek olarak görülmektedir. Topraksız kültür üretimlerinde kısa vegetasyonlu yeşillikleri herhangi bir hastalık ve zararlı etmeniyle karşılaştırmadan hızlı bir şekilde üretmek mümkün olmaktadır (Nicola et al. 2005; Nicola et al. 2007). Topraksız kültürde yetiştirme ortamı olarak genellikle torf, perlit, kaya yünü, Hindistan cevizi lifi kullanılmaktadır. Bölgemiz şartlarında findık zurufu tarımsal atık olması nedeniyle alternatif ortam olarak gözükmektedir. Fındık zurufu kompostlandıktan sonra sahip olduğu fiziksel özellikler ve bitki besin elementleri nedeniyle tarımsal üretimde farklı amaçlara yönelik kullanılmıştır (Pekşen 2001; Zeytin and Baran 2003; Özenç and Çaycı 2005; Özenç et al. 2006; Bender Özenç 2007; Çimen et al. 2007; Özçelik and Pekşen 2007; Bender Özenç and Özenç 2008; Aygün 2015). Fındık zurufu ilavesi toprağın biyolojik aktivitesini artırmakla birlikte toprak potasyum ve fosfor kapsamına da önemli katkılar vermektedir (Özenç and Çalışkan 2001). Zurufun uygulandığı toprak yapısına bağlı olarak toprakta toplam porozite ve makropor yüzdesi, hidrolik iletkenlik ve agregat stabilitesi gibi özelliklerin de olumlu etkilendiği ifade edilmektedir (Zeytin and Baran 2003). Bununla birlikte kimyasal etkiler bakımından findık zurufu hayvan gübrelerine nazaran daha az etkili olmaktadır (Özenç et al. 2006). Bu nedenle zurufun tek başına yetiştirme ortamı olarak kullanılması durumunda organik veya kimyasal gübrelerle desteklenmesi gerekmektedir. Bu çalışmada farklı oranlarda organik gübre ile zenginleştirilmiş findık zuruf kompostu ortamında yetiştirilen roka ve terenin bazı mineral madde içeriklerinin belirlenmesi amaçlanmıştır.

\section{Materyal ve Metot}

Çalş̧ma, Ordu ili $\left(40^{\circ} 96^{\prime} \mathrm{N}, 37^{\circ} 96^{\prime} \mathrm{E}\right)$ ekolojik koşullarında 1sıtmasız plastik serada yürütülmüştür. Yetiştiricilik 16 litre hacimli 75x16x14 cm boyutlara sahip plastik balkon tipi saksılarda yapılmış ve yetiştirme ortamı olarak findık zuruf kompostu kullanılmıştır. Yetiştirme ortamı findık zurufu azot içerikleri $\% 1,2,3$ ve 4 oranlarında olacak şekilde (hacimsel olarak sırasıyla $\% 5,10,15$ ve 20) organik gübre ile zenginleştirilmiştir. Kullanılan organik gübrenin içeriği Çizelge 1'de verilmiştir. Fındık zuruf kompostu kontrol uygulaması olarak alınmıştır.

Deneme planına göre organik gübre ilave edilen findık zurufları saksılara doldurulmuştur. Standart çeşit roka ve tere tohumları (Balıkesir Tohum) ilkbahar ve sonbahar yetiştirme dönemlerinde $2 \mathrm{~g} / \mathrm{m}^{2}$ olacak şekilde saksılara ekilmiştir. Tohum ekimi sonbahar döneminde 10 Eylülde, ilkbahar döneminde ise 28 Nisanda gerçekleştirilmiştir. Tohum ekimi sonrasında kapak materyali olarak $1 \mathrm{~cm}$ kalınlığında torf (Klasmann Potgrond H, Doktor Tarsa/Antalya) kullanılmıştır. Her bir saksı bir uygulama tekerrürü olarak kabul edilmiş ve çalışma 3 tekerrürlü olarak tesadüf parselleri deneme desenine göre kurulmuştur. Çalı̧̧mada herhangi bir ilave gübre uygulaması yapılmamıs, hasada kadar gerekli bakım işlemleri gerçekleştirilmiştir (Vural ve ark. 2000). Bitkilerde hasat keskin bir bıçak yardımıyla bitki büyüme bölgelerine zarar vermeyecek şekilde toprak seviyesinin $2 \mathrm{~cm}$ üzerinden yapılmıştır. İlkbahar döneminde ilk hasat 21 Mayısta, ikinci hasat 12 Haziranda gerçekleştirilmiştir. Sonbahar döneminde ilk hasat 10 Ekimde, ikinci hasat ise 12 Kasımda yapılmıştır. 
Çizelge 1. Çalışmada Kullanılan Organik Gübrenin Kimyasal İçeriği

\begin{tabular}{ccc}
\hline Özellikler & Miktar & Birim \\
\hline $\mathrm{N}$ & 4.98 & $(\%)$ \\
$\mathrm{C}$ & 26.78 & $(\%)$ \\
$\mathrm{P}_{2} \mathrm{O}_{5}$ & 4.97 & $(\%)$ \\
$\mathrm{K}_{2} \mathrm{O}$ & 5.76 & $(\%)$ \\
$\mathrm{Fe}$ & 112 & $(\mathrm{ppm})$ \\
$\mathrm{S}$ & 3190 & $(\mathrm{ppm})$ \\
$\mathrm{Zn}$ & 490 & $(\mathrm{ppm})$ \\
$\mathrm{Mo}$ & 18.4 & $(\mathrm{ppm})$ \\
$\mathrm{Ca}$ & 796 & $(\mathrm{ppm})$ \\
$\mathrm{Mg}$ & 306 & $(\mathrm{ppm})$ \\
$\mathrm{Nem}$ & 20 & $(\%)$ \\
$\mathrm{pH}$ & 7.5 & - \\
\hline
\end{tabular}

Hasat edilen yaprak örnekleri musluk suyunda yıkanarak $3 \mathrm{kez}$ saf sudan geçirilerek temizlenmiştir. Yaprak örnekleri bir kısmı ilk ağırlıkları belirlendikten sonra $65^{\circ} \mathrm{C}$ 'de 72 saat boyunca bırakılarak kurutma dolabında kurutulmuşlardır. Kurutulmuş örnekler değirmende öğütülerek makro-mikro element analizleri için hazır hale getirilmiştir. Yaprak örneklerinde azot belirlenmesinde Kjeldahl metodu kullanılmış, kuru yakma yöntemi ile elde edilen süzüklerden okuma gerçekleştirilmiștir. Fosfor miktarı sarı renk yöntemi kullanılarak spektrofotometrede, potasyum ise atomik absorbsiyon spektrofotometrede okunarak tayin edilmiştir (Kacar ve İnal 2008).

Çalışma sonuçlarının istatistiksel analizleri SPSS paket programından yararlanılarak yapılmışıtır.

\section{Bulgular}

Çalışmada farklı oranlarda organik gübre ile zenginleştirilmiş findık zurufu kompostunda yetiştirilen roka ve tere bitkilerinin farklı hasat dönemine göre bazı mineral madde içeriklerine etkisi incelenmiştir. Çalışma sonuçları bitki türlerine göre ayrı başlıklarda verilmiştir.

\subsection{Roka yapraklarında mineral madde miktarları}

Roka yapraklarinda azot miktarl

Organik gübre ilavesinin findık zurufu kompostunda yetiştirilen rokanın yapraklarındaki azot miktarına etkisi Çizelge 2'de verilmiştir.

Çizelge 2. Rokada Uygulamalara Göre Azot İçerikleri (\%)

\begin{tabular}{|c|c|c|c|c|}
\hline & & Sonbahar & İlkbahar & Ortalama \\
\hline \multirow{6}{*}{$\operatorname{Doz}(A)$} & Kontrol & $4.33 \mathrm{~d}$ & $1.00 \mathrm{f}$ & $2.67 \mathrm{D}$ \\
\hline & $\% 1 \mathrm{~N}$ & $4.83 \mathrm{~cd}$ & $2.17 \mathrm{e}$ & $3.50 \mathrm{C}$ \\
\hline & $\% 2 \mathrm{~N}$ & $5.50 \mathrm{~b}$ & $4.00 \mathrm{~d}$ & $4.75 \mathrm{~B}$ \\
\hline & $\% 3 \mathrm{~N}$ & $5.50 \mathrm{~b}$ & $4.17 \mathrm{~d}$ & $4.83 \mathrm{~B}$ \\
\hline & $\% 4 \mathrm{~N}$ & $6.50 \mathrm{a}$ & $5.17 \mathrm{bc}$ & $5.83 \mathrm{~A}$ \\
\hline & LSD & \multicolumn{2}{|c|}{$0.60 * *$} & $0.42 * *$ \\
\hline \multirow{3}{*}{ Hasat (B) } & 1. Hasat & $5.47 a$ & $4.07 b$ & $4.77 \mathrm{~A}$ \\
\hline & 2. Hasat & $5.20 a$ & $2.53 c$ & $3.87 \mathrm{~B}$ \\
\hline & LSD & \multicolumn{2}{|c|}{$0.38 * *$} & $0.27 * *$ \\
\hline \multirow[t]{2}{*}{ Yetiştirme } & Ortalama & $5.33 \mathrm{~A}$ & $3.30 \mathrm{~B}$ & \\
\hline & LSD & \multicolumn{2}{|c|}{$0.27 * *$} & \\
\hline
\end{tabular}

Roka yapraklarındaki azot içerikleri incelendiğinde tüm uygulama faktörleri bakımından rokada azot miktarlarında istatistiksel anlamda farklılıklar görülmüştür $(\mathrm{p}<0.05)$. Yetiştirme dönemleri açısından sonbahar döneminde yapraklar daha yüksek azot içerirken ilkbahar döneminde azot miktarında \%61 
oranında bir düşüş (\%5.33-3.30) meydana gelmiştir. Yetiştirme ortamına ilave edilen organik gübre miktarına bağlı olarak roka yapraklardaki azot miktarı artmıştır. Kontrol uygulamasına göre roka yapraklarındaki azot miktarında iki kattan fazla artış meydana gelmiştir (\%2.67-5.83). Hasat dönemine göre roka yapraklarındaki azot miktarı değişmiş ve ilk hasatta yaprak azot içerikleri daha yüksek bulunmuştur (Çizelge 2).

Roka yapraklarında fosfor miktarı

Rokada yetiştiriciliğinde uygulamaların yapraklardaki fosfor içeriğine etkisi Çizelge 3 'te verilmiştir.

Çizelge 3. Rokada Uygulamalara Göre Fosfor İçerikleri (\%)

\begin{tabular}{|c|c|c|c|c|}
\hline & & Sonbahar & İlkbahar & Ortalama \\
\hline \multirow{6}{*}{ Doz (A) } & Kontrol & $0.34 \mathrm{bc}$ & $0.12 \mathrm{~d}$ & $0.23 \mathrm{D}$ \\
\hline & $\% 1 \mathrm{~N}$ & $0.36 \mathrm{bc}$ & $0.32 \mathrm{c}$ & $0.34 \mathrm{C}$ \\
\hline & $\% 2 \mathrm{~N}$ & $0.38 \mathrm{~b}$ & $0.37 \mathrm{bc}$ & $0.38 \mathrm{~B}$ \\
\hline & $\% 3 \mathrm{~N}$ & $0.40 \mathrm{~b}$ & $0.40 \mathrm{~b}$ & 0.40 \\
\hline & $\% 4 \mathrm{~N}$ & $0.39 \mathrm{~b}$ & $0.46 \mathrm{a}$ & $0.43 \mathrm{~A}$ \\
\hline & LSD & \multicolumn{2}{|c|}{$0.05 * *$} & $0.04 * *$ \\
\hline \multirow{3}{*}{ Hasat (B) } & 1. Hasat & $0.42 a$ & $0.35 b$ & $0.38 \mathrm{~A}$ \\
\hline & 2. Hasat & $0.34 b$ & $0.32 b$ & 0.33 B \\
\hline & LSD & \multicolumn{2}{|c|}{$0.03^{*}$} & $0.02 * *$ \\
\hline \multirow[t]{2}{*}{ Yetiştirme } & Ortalama & $0.38 \mathrm{~A}$ & $0.33 \mathrm{~B}$ & \\
\hline & LSD & \multicolumn{2}{|c|}{$0.02 * *$} & \\
\hline
\end{tabular}

öd.: Önemli değil; *: $\mathrm{p}<0.05 ; * *: \mathrm{p}<0.01$

Tüm uygulama faktörlerinin yapraklardaki fosfor içeriklerini istatistiksel anlamda etkilediği görülmüştür $(p<0.05)$. Findık zurufu kompostuna ilave edilen organik gübre dozuna bağlı olarak roka yapraklarında fosfor içeriği artmıştır. Yetiştirme dönemleri incelendiğinde sonbahar döneminde ilkbahar dönemine göre nispeten daha yüksek fosfor değerleri elde edilmiştir. Sonbahar döneminde yapraklardaki ortalama fosfor miktarı $\% 0.38$ olarak bulunurken, bu değer ilkbahar döneminde düşüş göstermiş ve $\% 0.33$ olarak belirlenmiştir. Kontrol uygulamasına göre organik gübre ilavesiyle roka yapraklardaki fosfor içeriği \%86'ya varan oranlarda artmıştır. İlk hasatlara göre ikinci hasatlarda roka yapraklarındaki fosfor içeriklerinde azalmalar meydana gelmiştir (Çizelge 3).

\section{Roka yapraklarinda potasyum miktart}

Uygulamaların roka yapraklarındaki potasyum miktarına etkisi Çizelge 4'de görülmektedir.

Cizelge 4. Rokada Uygulamalara Göre Potasyum İçerikleri (\%)

\begin{tabular}{|c|c|c|c|c|}
\hline & & Sonbahar & İlkbahar & Ortalama \\
\hline \multirow{6}{*}{ Doz (A) } & Kontrol & $4.87 \mathrm{ab}$ & $2.80 \mathrm{e}$ & $3.84 \mathrm{C}$ \\
\hline & $\% 1 \mathrm{~N}$ & $4.91 \mathrm{ab}$ & $3.11 \mathrm{de}$ & $4.01 \mathrm{BC}$ \\
\hline & $\% 2 \mathrm{~N}$ & $5.47 \mathrm{a}$ & $3.56 \mathrm{~cd}$ & $4.51 \mathrm{~A}$ \\
\hline & $\% 3 \mathrm{~N}$ & $5.13 \mathrm{ab}$ & $3.77 \mathrm{~cd}$ & $4.45 \mathrm{AB}$ \\
\hline & $\% 4 N$ & $4.50 \mathrm{~b}$ & $4.15 \mathrm{c}$ & $4.32 \mathrm{AB}$ \\
\hline & LSD & \multicolumn{2}{|c|}{$0.71 * *$} & $0.50^{*}$ \\
\hline \multirow{3}{*}{ Hasat (B) } & 1. Hasat & 5.28 & 3.73 & $4.51 \mathrm{~A}$ \\
\hline & 2. Hasat & 4.67 & 3.22 & $3.95 \mathrm{~B}$ \\
\hline & LSD & \multicolumn{2}{|c|}{ öd. } & $0.32 * *$ \\
\hline \multirow[t]{2}{*}{ Yetiştirme } & Ortalama & $4.98 \mathrm{~A}$ & $3.48 \mathrm{~B}$ & \\
\hline & LSD & \multicolumn{2}{|c|}{$0.32 * *$} & \\
\hline
\end{tabular}


Çizelge 4'de verilen potasyum değerleri incelendiğinde, organik gübre dozları, yetiştirme dönemi ve hasat dönemine göre roka yapraklarındaki potasyum miktarı istatistiksel olarak farklı bulunmuştur $(\mathrm{p}<0.05)$. Sonbahar döneminde roka yapraklarında potasyum içerikleri benzer bulunmuş, ilkbahar döneminde ise \%1, 2 ve 3 ilave organik gübre dozları potasyum içeriğini artırmıştır. Yetiştirme dönemleri açısından yaprak potasyum içerikleri değerlendirildiğinde, sonbahar döneminde yetiştirilen rokalar ilkbahar döneminde yetiştirilen rokalara nazaran \%43 daha fazla potasyum içermişlerdir. Potasyum içerikleri bakımından hasat dönemleri irdelendiğinde ikinci hasada göre ilk hasatta daha yüksek potasyum miktarı elde edilmiştir.

\subsection{Tere yapraklarında mineral madde miktarları}

\section{Tere yapraklarında azot miktarı}

Organik gübre ilave edilmiş findık zuruf kompostunda yetiştirilen tere yapraklarının azot içeriklerindeki değişim Çizelge 5'de verilmiştir.

Çizelge 5. Terede Uygulamalara Göre Azot İçerikleri (\%)

\begin{tabular}{|c|c|c|c|c|}
\hline & & Sonbahar & İlkbahar & Ortalama \\
\hline \multirow{6}{*}{$\operatorname{Doz}(\mathbf{A})$} & Kontrol & $3.67 \mathrm{e}$ & $1.38 \mathrm{~g}$ & $2.53 \mathrm{D}$ \\
\hline & $\% 1 \mathrm{~N}$ & $5.67 \mathrm{~b}$ & $3.00 \mathrm{f}$ & $4.33 \mathrm{C}$ \\
\hline & $\% 2 \mathrm{~N}$ & $6.00 \mathrm{ab}$ & $3.50 \mathrm{ef}$ & $4.75 \mathrm{~B}$ \\
\hline & $\% 3 \mathrm{~N}$ & $6.50 \mathrm{a}$ & $4.50 \mathrm{~d}$ & $5.50 \mathrm{~A}$ \\
\hline & $\% 4 \mathrm{~N}$ & $6.33 \mathrm{a}$ & $5.11 \mathrm{c}$ & $5.72 \mathrm{~A}$ \\
\hline & LSD & \multicolumn{2}{|c|}{$0.55 * *$} & $0.39 * *$ \\
\hline \multirow{3}{*}{ Hasat (B) } & 1. Hasat & $5.73 a$ & $4.11 b$ & $4.92 \mathrm{~A}$ \\
\hline & 2. Hasat & $5.53 a$ & $2.89 c$ & $4.21 \mathrm{~B}$ \\
\hline & LSD & \multicolumn{2}{|c|}{$0.35 * *$} & $0.25^{* *}$ \\
\hline \multirow[t]{2}{*}{ Yetiştirme } & Ortalama & $5.63 \mathrm{~A}$ & $3.50 \mathrm{~B}$ & \\
\hline & LSD & \multicolumn{2}{|c|}{$0.25 * *$} & \\
\hline
\end{tabular}

Çalışmada ele alınan uygulama faktörlerinin azot içeriklerine etkisi istatistiksel anlamda önemli bulunmuştur $(\mathrm{p}<0.05)$. Organik gübre ilavesi kontrole göre tere yapraklarındaki azot içeriği dikkat çekici şekilde artış göstermiştir (\%2.53-\%5.72). Sonbahar döneminde azot içerikleri ilkbahar dönemine göre yaklaşık \%60 daha fazla bulunmuştur. Benzer şekilde ilk hasatta yapraklardaki azot içeriğinin ikinci hasada göre daha yüksek olduğu belirlenmiş, bu durum ilkbahar döneminde daha belirgin olmuştur. İlkbahar döneminde organik gübre ilavesi kontrol uygulamasına göre tere yapraklarındaki azot miktarını yaklaşık \%117-270 arasında değişen oranlarda arttırmıştır (Çizelge 5).

Tere yapraklarında fosfor miktarl

Terede uygulamalara göre yaprak fosfor içerikleri Çizelge 6'da gösterilmiştir.

Çizelge 6'da verilen değerler incelendiğinde uygulama faktörleri tere yapraklarının fosfor içeriklerinde istatistiksel anlamda farklılıklar meydana getirmiştir $(\mathrm{P}<0.005)$. İlkbahar döneminde yetiştirilen tere yapraklarındaki fosfor içerikleri sonbahar döneminde yetiştirilenlere göre daha yüksek bulunmuştur. Sonbahar yetiştirme döneminde \%1 ve 2 organik gübre dozunda yapraklardaki fosfor içeriklerinin kontrole göre arttığ 1 , doz arttıkça azaldığı tespit edilmiştir. \%4 uygulamasında kontrol uygulamasından daha düşük bir değer elde edilmiştir. Sonbaharda ilk hasatta fosfor miktarı (\%0.93) ikinci hasada (\%0.27) göre önemli ölçüde yüksek bulunmuştur. İlkbahar döneminde ise istatistiksel olarak aralarında fark bulunmamış olmakla birlikte P içeriğinin arttığı saptanmıştır. Uygulama dozuna bağlı olarak tere yapraklarında yaprak fosfor içerikleri değişmemekle birlikte yetiştirme dönemi*uygulama dozu interaksiyonunda fosfor içerikleri arasında bir fark belirlenmiştir $(\mathrm{p}<0.05)$. 
Cizelge 6. Terede Uygulamalara Göre Fosfor İcerikleri (\%)

\begin{tabular}{|c|c|c|c|c|}
\hline & & Sonbahar & İlkbahar & Ortalama \\
\hline \multirow{6}{*}{$\operatorname{Doz}(\mathbf{A})$} & Kontrol & $0.50 \mathrm{~cd}$ & $0.59 \mathrm{bcd}$ & 0.55 \\
\hline & $\% 1 \mathrm{~N}$ & $0.67 \mathrm{abcd}$ & $0.50 \mathrm{~cd}$ & 0.58 \\
\hline & $\% 2 \mathrm{~N}$ & $0.83 \mathrm{abc}$ & $0.83 \mathrm{abc}$ & 0.83 \\
\hline & $\% 3 \mathrm{~N}$ & $0.67 \mathrm{abcd}$ & $1.00 \mathrm{a}$ & 0.83 \\
\hline & $\% 4 \mathrm{~N}$ & $0.33 \mathrm{~d}$ & $0.94 \mathrm{ab}$ & 0.64 \\
\hline & LSD & \multicolumn{2}{|c|}{$0.36^{*}$} & öd. \\
\hline \multirow{3}{*}{ Hasat (B) } & 1. Hasat & $0.93 a$ & $0.71 a$ & $0.82 \mathrm{~A}$ \\
\hline & 2. Hasat & $0.27 b$ & $0.84 a$ & $0.55 B$ \\
\hline & LSD & \multicolumn{2}{|c|}{$0.23 * *$} & $0.16^{* * *}$ \\
\hline \multirow[t]{2}{*}{ Yetiştirme } & Ortalama & $0.60 \mathrm{~B}$ & $0.77 A$ & \\
\hline & LSD & \multicolumn{2}{|c|}{$0.16^{*}$} & \\
\hline
\end{tabular}

Tere yapraklarında potasyum miktarı

Tere yapraklarında uygulamalara göre potasyum içeriklerinin değişimi Çizelge 7'de verilmiştir.

\begin{tabular}{|c|c|c|c|c|}
\hline & & Sonbahar & İlkbahar & Ortalama \\
\hline \multirow{6}{*}{$\operatorname{Doz}(\mathbf{A})$} & Kontrol & $4.87 \mathrm{ab}$ & $2.80 \mathrm{f}$ & $3.84 \mathrm{~B}$ \\
\hline & $\% 1 \mathrm{~N}$ & $4.91 \mathrm{ab}$ & $3.11 \mathrm{ef}$ & $4.01 \mathrm{AB}$ \\
\hline & $\% 2 \mathrm{~N}$ & $5.47 \mathrm{a}$ & $3.56 \mathrm{de}$ & $4.51 \mathrm{~A}$ \\
\hline & $\% 3 \mathrm{~N}$ & $5.13 \mathrm{ab}$ & $3.77 \mathrm{de}$ & $4.45 \mathrm{~A}$ \\
\hline & $\% 4 \mathrm{~N}$ & $4.50 \mathrm{bc}$ & $4.15 \mathrm{~cd}$ & $4.32 \mathrm{AB}$ \\
\hline & LSD & \multicolumn{2}{|c|}{$0.71 * *$} & $0.50 *$ \\
\hline \multirow{3}{*}{ Hasat (B) } & 1. Hasat & 5.28 & 3.73 & $4.51 \mathrm{~A}$ \\
\hline & 2. Hasat & 4.67 & 3.22 & $3.95 \mathrm{~B}$ \\
\hline & LSD & \multicolumn{2}{|c|}{ öd. } & $0.32 * *$ \\
\hline \multirow[t]{2}{*}{ Yetiştirme } & Ortalama & $4.98 \mathrm{~A}$ & $3.48 \mathrm{~B}$ & \\
\hline & LSD & \multicolumn{2}{|c|}{$0.32 * *$} & \\
\hline
\end{tabular}

Fındık zurufu kompostuna ilave edilen organik gübre dozları tere yapraklarının potasyum içerikleri üzerine tüm uygulama faktörleri bakımından istatistiksel anlamda etkili olmuştur $(\mathrm{P}<0.005)$. Kontrol bitkilerine göre organik gübre ilavesi bitkilerde potasyum içeriğini arttırıcı yönde etki göstermiş, doz artışına bağlı olarak bu etki bir miktar azalma eğiliminde olmuştur. Yetiştirme dönemi açısından uygulama dozlarının potasyum içeriklerine etkileri incelendiğinde sonbahar dönemi bitkilerinde potasyum içerikleri benzer bulunmuş, ilkbahar döneminde ise potasyum içeriği önemli ölçüde artış göstermiştir (\%2.34-4.92). Sonbahar dönemi yetiştiriciliğinde tere yapraklarındaki potasyum içerikleri \%5.26 iken ilkbahar döneminde bu değer \%3.94'e düşmüştür. Aynı şekilde yapraklardaki potasyum içeriği ikinci hasada (\%3.91) göre ilk hasatta (\%5.30) daha yüksek bulunmuştur.

\section{Tartışma ve Sonuç}

Roka yapraklarının azot içerikleri yetiştirme dönemlerine göre irdelendiğinde sonbahar döneminde ilkbahar dönemine göre daha yüksek değerler elde edilmiştir. Eşiyok ve ark. (2006b)'nın rokada yaptıkları çalışmada sonbahar döneminde azot içeriklerinin daha yüksek bulunduğunu ifade etmeleri bizim bulgularımızı desteklemektedir. Brkic et al. (2017), Hırvatistan'ın değişik şehirlerinde marul, ıspanak, karalahana ve pazı bitkilerinde yaptıkları çalışmada sonbahar döneminde hasat edilen sebzelerin 
ilkbaharda hasat edilen sebzelerden yaklaşık \%83.71 oranında daha fazla miktarda nitrat içerdiklerini ve sonbahar döneminde rokalarda nitrat miktarının $4354.9 \mathrm{mg} / \mathrm{kg}$ olduğunu belirtmişlerdir.

Çalışmamızda birinci hasatta ikinci hasada göre daha yüksek azot içerikleri elde edilmiştir. Omirou ve ark. (2012)'nın rokada erken dönemde hızlı bitki gelişimine bağlı olarak azot içeriklerinin daha yüksek olduğunu ifade etmesi bizim bulgumuzu desteklemektedir. Organik gübre dozlarının roka yapraklarında azot içeriğine etkisi incelendiğinde ise en yüksek azot içeriği $\% 5.83$ ile $\% 4$ oranında azot içeren organik gübre ilavesi yapılmış yetiştirme ortamından, en düşük azot içeriği ise \%2.67 ile kontrol uygulamasından elde edilmiştir. Yetiştirme ortamına ilave edilen organik gübre dozu arttıkça yaprakların azot içerikleri de artmıştır. Benzer çalışmalarda azot içerikleri \%5.76 (Akçay Shakernagad 2000), \%2.38-2.42 (Elgin 2003), \%3.92-4.63 (Cavarianni et al. 2008), \%2.1-2.4 (Bozokalfa et al. 2009), \%2.42-2.61 (Demiral ve ark. 2009), \%1.98-2.74 (Eşiyok et al. 2010), \%2.94-5.23 (Barlas et al. 2011) ve \%2.87-3.61 (Eşiyok ve ark. 2006b) oranlarında bulunmuştur. Bizim çalışmada organik gübre ilave edilen ortamlarda yetiştirilen rokalarda ortalama \%4.71 oranında azot içeriği belirlenmiş olup, önceki çalışmalara göre bu değerin bir miktar yüksek olduğu görülmektedir. Marul, 1spanak gibi yapraklı sebzeler genel olarak yüksek miktarda azot içeriklerine (Iammarino et al. 2014) sahip olmakla birlikte, Karadeniz Bölgesinde bulutlu gün sayısının fazla olması da roka bitkilerinin daha fazla azot biriktirmelerine neden olmaktadır. Rokada organik gübreleme ile azot içerikleri değişiminde iklim ve çevre faktörlerinin yanında, besin alımı ve taşınmasının da etkili olduğu hususu göz ardı edilmemelidir.

Roka yaprakları fosfor içerikleri açısından değerlendirildiğinde yetiştirme ortamına ilave edilen organik gübre dozu arttıkça fosfor alımında bir artış olduğu görülmüştür. Benzer şekilde ilk hasatta yapraklarda daha yüksek fosfor içerikleri belirlenmiştir. Yetiştirilme dönemleri açısından sonbahar döneminde hasat edilen roka yapraklarında daha yüksek fosfor içeriği elde edilmiştir. Uygulama dozları açısından bakıldığında en yüksek fosfor içeriği \%4 azot içeren yetiştirme ortamından (\%0.43) elde edilirken, en düşük fosfor içeriği kontrol uygulamasından elde edilmiştir. Roka yapraklarında fosfor içeriklerini belirleyen önceki çalışmalarda \%0.35-0.59 (Akçay Shakernagad 2000), \%0.44-0.56 (Elgin 2003), \%0.34-0.41 (Cavarianni et al. 2008), \%0.48-0.52 (Bozokalfa et al. 2009), \%0.49 (Eşiyok et al. 2010) ve \%0.12-0.27 (Barlas et al. 2011) şeklinde sonuçlar belirlenmiştir. Çalışmamızda fosfor içerikleri önceki çalışma sonuçları ile paralellik göstermiştir.

Roka yapraklarının organik gübre uygulamalarına göre içermiş oldukları potasyum miktarları irdelendiğinde uygulama dozunun artışına bağlı olarak potasyum içeriğinde bir artış olduğu görülmüştür. Yetiştirme dönemleri açısından bakıldığında sonbahar döneminde daha yüksek potasyum miktarı elde edilmiştir. Hasat dönemlerinde birinci hasatta değerler daha yüksek çıkmıştır. Organik gübre dozlarına göre en yüksek potasyum miktarı \%2 N dozundan (\%4.51), en düşük ise kontrol uygulamasından elde edilmiştir. Organik gübre dozunun artması bitkilerin daha yüksek mineral madde almasına neden olmuştur. Bu konuda yapılan çalışmalarda \%6.14 (Akçay Shakernagad 2000), \%2.55-2.56 (Elgin 2003), $\% 1.83$ (Kawashima and Soares 2003), \%4.33-5.49 (Cavarianni et al. 2008), \%2.69-4.0 (Bozokalfa et al. 2009) ve \%4.42-7.23 (Eşiyok et al. 2010) oranlarında potasyum içerikleri belirlenmiştir. Bu çalışmalarda potasyum içeriklerinin \%1.83-7.23 gibi çok geniş aralıkta olduğu ve bizim çalışmamızda \%2.80-5.47 arasında değişen potasyum içeriklerinin literatürle uyumlu olduğu bulunmuştur.

Çalışmada tere yaprakları da mineral madde içerikleri açısından incelenmiştir. Tere yapraklarında tüm uygulama faktörleri azot içeriklerini istatistiksel anlamda etkilemiştir. Yetiştirme dönemleri açısından bakıldığında sonbahar döneminde tere yapraklarındaki azot içerikleri ilkbahar dönemine göre daha yüksek bulunmuştur. Benzer sonuçlara hasat dönemleri açısından da ulaşılmış ve ilk hasatta yapraklardaki azot içeriği ikinci hasada göre daha yüksek bulunmuştur. Organik gübre uygulamaları yapraklarda azot içeriğini belirgin derecede arttırmıştır. İlkbahar döneminde organik gübre dozları kontrol uygulamasına göre tere yapraklarındaki azot miktarını yaklaşık 2.17-3.70 kat arttırmıştır. Uygulama yapılan terelerde azot içerikleri kontrole göre yüksek bulunmuş ve \%3.00-6.50 arasında değişmiştir. Eşiyok ve ark. (2006b) tarafından yapılan çalışmada terelerde azot içeriği \%1.26-4.50 arasında bulunmuştur. Bir başka çalışmada da terelerde azot içeriği ilkbahar döneminde \%2.94 ve sonbahar döneminde \%3.79 (Eşiyok ve ark. 2006a) olarak saptanmıştır. Sonbahar döneminde azot içeriğinin yüksek bulunması bizim bulgularımızla uyumludur. Ayrıca bizim çalışmamızda tere yapraklarında daha yüksek azot içerikleri de belirlenmiştir. Bölgemiz ekolojik koşullarında bulutlu gün sayısının fazla olması bitkilerin daha fazla azot akümüle etmelerine neden olmuştur.

Tere yapraklarının fosfor içerikleri açısından bir değerlendirme yapıldığında, ilkbahar döneminde daha yüksek değerler elde edilmiştir. Tere yapraklarında fosfor içerikleri \%0.33-1.00 arasında değişmiştir. 
Eşiyok ve ark. (2006a) yaptıkları çalışmada tere yapraklarında fosfor miktarının ortalama olarak \%0.340.54 arasında değiştiğini, ilkbahar döneminde $\% 0.45$ ve sonbahar döneminde $\% 0.53$ olduğunu bildirmişlerdir. Sadece ilk hasatlar açısından bir değerlendirme yapılırsa bizim çalışmamızda da sonbahar döneminde daha yüksek değerler elde edilmiştir. Sonbahar döneminde birinci hasat sonrası mevsimsel olarak sıcaklıkların azalmaya başlaması bitkilerde fosfor alımını engellemiş, bu da fosfor değerlerinin azalmasına neden olmuş olabilir.

Çalışmada terenin potasyum içerikleri üzerine ele alınan uygulama faktörleri istatistiksel anlamda etkili olmuştur. Artan gübre dozu tere yapraklarındaki potasyum miktarını arttırmıştır. İlkbahar yetiştirme döneminde potasyum içerikleri daha düşük bulunmuştur. Sonbahar döneminde tere yapraklarındaki potasyum içeriği \%5.26 iken ilkbahar döneminde bu değer \%3.94'e düşmüştür. Hasat dönemi açısından da benzer sonuçlara ulaşılmış ve ikinci hasatta yaprakların potasyum içeriği düşmüştür. Eşiyok ve ark. (2006a) yaptıkları çalışmada tere yapraklardaki potasyum miktarını ilkbahar döneminde \%2.71, sonbahar döneminde \%2.82 olarak belirlemişlerdir. Bu sonuçlar bulgularımızla uyumlu bulunmakla birlikte, bizim çalışmamızda çok daha yüksek potasyum içerikleri de elde edilmiştir. Bu durumun bitki beslenme şartlarından kaynaklandığı düşünülmektedir.

Tüm bulgular ve tartışmalar ışığında çalışma genel olarak değerlendirildiğinde; findık zurufunun bir ortam materyali olarak kullanılabileceği, zurufun uygun şekilde kompostlandıktan sonra ortam veya toprak katkı maddesi olarak tarıma kazandırılması gerektiği düşünülmektedir. Yeşilliklerde ikinci hasat yerine kademeli ekim zamanı ile yaprak kalitesi daha iyi korunabilir. Kompostlanmış fındık zuruf ortamının diğer yeşilliklerde denenmesi tarımsal üretim desenlerinin gelişimine katkı sunabilir.

\section{Bilgilendirme}

Bu çalışma Gülnur KARAAL BOZKURT’un yüksek lisans tez çalışmasından üretilmiştir.

\section{Kaynaklar}

Akçay Shakernagad B (2000). Bazı Doğal ve Yapay Gübrelerin Roka Bitkisinin Verim ve Kalite Özellikleri Üzerine Etkisi. E.Ü. Fen Bilimleri Enstitüsü Bahçe Bitkileri Anabilim Dalı, Yüksek Lisans Tezi, Bornova/İzmir.

Aygün S (2015). Fındık Zurufu Kompostunun Toprak Kalitesi Üzerine Etkisi. ODÜ Fen Bilimleri Enstitüsü Toprak ve Bitki Besleme Anabilim Dalı, Yüksek Lisans Tezi, 91 s., Ordu.

Barlas NT, Irget ME, Tepecik M (2011). Mineral content of the rocket plant (Eruca sativa). African Journal of Biotechnology, 10(64):14080-14082.

Bender Özenç D (2006). Effects of composted hazelnut husk on growth of tomato plants. Compost Science \& Utilization, 14(4):271-275.

Bender Özenç D, Özenç N (2008). Short-term effects of hazelnut husk compost and organic amendment applications on clay loam soil. Compost Science \& Utilization, 16(3):192-199.

Bozokalfa MK, Yağmur B, İlbi H, Eşiyok D, Kavak S (2009). Genetic variability for mineral concentration of Eruca sativa L. and Diplotaxis tenufolia L. accessions. Crop Breeding and Applied Biotechnology, 9:372-381.

Brkic D, Bosnir J, Bevardi M, Boskovic AG, Milos S, Lasic D, Krivohlavek A, Racz A, MojsovicCuic A, Trstenjaket NU (2017). Nitrate in leafy green vegetables and estimated intake. Afr J Tradit Complement Altern Med. 14(3):31-41.

Cavarianni RL, Filho ABC, Cazetta JO, May A, Corradi MM (2008). Nutrient contents and production of rocket as affected by nitrogen concentrations in the nutritive solution. Sci. Agric. (Piracicaba, Braz.), 65(6):652-658.

Chang AC, Yang TY, Riskowski GL (2013). Ascorbic acid, nitrate, and nitrite concentration relationship to the 24 hour light/dark cycle for spinach grown in different conditions. Food Chem. 138:382-388. 
Colonna E, Rouphael Y, Barbieri G, De Pascale S (2016). Nutritional quality of ten leafy vegetables harvested at two light intensities. Food Chem. 199:702-710.

Çimen F, Ok S, Kayran C, Demirci S, Bender Özenç D, Özenç N (2007). Characterization of humic materials extracted from hazelnut husk and hazelnut husk amended soils. Biodegradation, 18(3):295-301.

Demir H (2007). Yaprağı Yenen Sebzeler. 1. Baskı, 191 s., Hasad Yayınc1lık, İstanbul.

Demiral MA, Ay M, Soral F, Tekin M (2009). Effect of nitrogen on growth and nitrate accumulation of some leafy vegetables. ADÜ Ziraat Fakültesi Dergisi, 6(2):3-7.

Elgin Ç (2003). Bazı Ticari Organik Gübre Seviyelerinin Roka Bitkisinin Verim ve Mineral Madde İçeriği Üzerine Etkileri. E.Ü. Fen Bilimleri Enstitüsü Bahçe Bitkileri Anabilim Dalı, Yüksek Lisans Tezi, Bornova/İzmir.

Eşiyok D (2012). Kışlık ve Yazlık Sebze Yetiştiriciliği, Meta Basım Matbaacılık, İzmir.

Eşiyok D, Bozokalfa MK, Ongun AR, Tepecik M, Okur B, Kaygısız T (2006a). Farklı organik gübrelerin tere (Lepidium sativum L.) yetiştiriciliğinde verim ve bazı kalite özellikleri üzerine etkisi. Türkiye 3. Organik Tarım Sempozyumu. Atatürk Bahçe Kültürleri Merkez Araştırma Enstitüsü, Yalova.

Eşiyok D, Bozokalfa MK, Yağmur B, Kaygısız Aşçığul T (2010). Nutrional value and economic plant properties of Eruca sativa L. accessions. The Cruciferae Newsletter (vol. 29). Agrocampus Quest- Univ. Rennes1 Plant and Genetic and Biotechnology Laboratory, France.

Eşiyok D, Okur B, Tuncay Ö, Yağmur B, Uğur A (2006b). Roka ve terede toplam glukozinolat miktarlarının ekim zamanı ve gübre formlarıyla değişiminin saptanması üzerinde araştırmalar. TÜBİTAK Projesi No:2006-206.

Gutierrez DR, Chaves AR, Rodriguez SDC (2017). Use of UV-C and gaseous ozone as sanitizing agents for keeping the quality of fresh-cut rocket (Eruca sativa Mill). Journal of Food Processing and Preservation, 41:e12968.

Iammarino M, Di Taranto A, Cristino M. (2014). Monitoring of nitrites and nitrate levels in leafy vegetables (spinach and lettuce): A contribution to risk assessment. J Sci Food Agric. 15:773-778.

Kacar B, İnal A. (2008). Bitki Analizleri. Nobel Yayınevi, 891 s., Ankara.

Kawashima LM, Soares LMV (2003). Fractionation study of mineral elements in raw and cooked leaf vegetables consumed in Southern Brazil. Alim. Nutr., Araraquara, 14(1):9-16.

Khanam UKS, Oba S, Yanase E, Murakami Y (2012). Phenolic acids, flavonoids and total antioxidant capacity of selected leafy vegetables. Journal of Functional Foods, 4(4):979-987.

Morales M, Janick J (2002). Arugula: A promising specialty leaf vegetable. In: J. Janick, A. Whipkey (ed.), Trends in new crops and uses. ASHS Press, Alexandria, VA. p.418-423.

Nicola S, Hoeberechts J, Fontana E (2005). Comparison between traditional and soilless culture systems to produce rocket (Eruca sativa) with low nitrate content. Acta Hortic. 697:549-555.

Nicola S, Hoeberechts J, Fontana E (2007). Ebb-and-flow and floating systems to grow leafy vegetables: a review for rocket, corn salad, garden cress and purslane. Acta Hortic. 747:585-593.

Omirou M, Papastefanou C, Katsarou D, Papastylianou I, Passam HC, Ehaliotis C, Papadopoulou KK (2012). Relationships between nitrogen, dry matter accumulation and glucosinolates in Eruca sativa Mills. The applicability of the critical NO3-N levels approach. Plant Soil, 354:347-358. 
Özçelik E, Pekşen A (2007). Hazelnut husk as a substrate for the cultivation of shiitake mushroom (Lentinula edodes). Bioresource Technology, 98:2652-2658.

Özenç N, Bender Özenç D, Çaycı G (2006). Effects of hazelnut husk compost, peat, farmyard manure and chicken manure on soil organic matter and nutrition and hazelnut yield. $18^{\text {th }}$ International Soil Meeting (ISM) on Soil Sustaining Life Earth, Managing Soil and Technology, May 22-26, Proceeding Vol II, pp. 937-945, Şanliurfa, Turkey.

Özenç N, Çalışkan N (2001). Effects of husk compost on hazelnut yield and quality. Acta Hortic. 556:559-566.

Özenç N, Çaycı G (2005). The Effects of hazelnut husk and other organic materials on hazelnut yield, some soil properties and quality. Acta Hortic. 686:297-308.

Pekşen A (2001). Fındık zurufundan hazırlanan yetiştirme ortamlarının pleurotus sajor-caju mantarının verimine ve bazı kalite özelliklerine etkisi. Bahçe, 30(1-2):37-43.

Santamaria P, Elia A (1997). Producing nitrate free endive heads: effect of nitrogen form on growth, yield and ion composition of endive. J Am Soc Hortic Sci. 122:140-145.

Santamaria P, Elia A, Serio F (2002). Effect of solution nitrogen concentration on yield, leaf element content, and water and nitrogen use efficiency of three hydroponically-grown rocket salad genotypes. J Plant Nutr. 25:245-258.

Vural H, Eşiyok D, Duman İ (2000). Kültür Sebzeleri (Sebze Yetiştirme), Ege Üniversitesi Ziraat Fakültesi Bahçe Bitkileri Bölümü, İzmir, (2000).

Zeytin S, Baran A (2003). Influences of composted hazelnut husk on some physical properties of soils. Bioresource Technology, 88(3):241-244. 